\title{
Case Report Methadone Induced Sensorineural Hearing Loss
}

\author{
Chadi Saifan, Daniel Glass, Iskandar Barakat, and Suzanne El-Sayegh \\ Department of Medicine, Staten Island University Hospital, 475 Seaview Avenue, Staten Island, NY 10305, USA
}

Correspondence should be addressed to Chadi Saifan; chadisaifan@hotmail.com

Received 13 March 2013; Accepted 18 June 2013

Academic Editor: Ting Fan Leung

Copyright (C) 2013 Chadi Saifan et al. This is an open access article distributed under the Creative Commons Attribution License, which permits unrestricted use, distribution, and reproduction in any medium, provided the original work is properly cited.

\begin{abstract}
Background. Sudden sensorineural hearing loss (SSHL) caused by opiate abuse or overuse has been well documented in the medical literature. Most documented case reports have involved either heroin or hydrocodone/acetaminophen. Recently, case reposts of methadone induced SSHL have been published. Case Report. We present the case of a 31-year-old man who developed SSHL after a methadone overdose induced stupor. He was subsequently restarted on methadone at his regular dose. On follow-up audiometry exams, he displayed persistent moderately severe sensorineural hearing loss bilaterally. Discussion. This case is notable because unlike all but one previously reported case, the patient-who was restated on methadone-did not make a complete recovery. Conclusion. Methadone overuse in rare cases causes SSHL.
\end{abstract}

\section{Case Report}

Mr. A. L is a 31-year-old man who was brought in by ambulance to the emergency department (SIUH South) after being found by his mother confused and stuporous at home. EMS reported that he was found apneic which resolved with naloxone. Mr. A. L has a known medical history of polysubstance abuse. He is also known to have depression and anxiety with recent admission to the psychiatric ward secondary to suicide attempt (wrist cut). He was tapered off benzodiazepines and started on fluoxetine. He had also recently been placed on a methadone program and follows with the methadone clinic for that matter. The patient arrived to the emergency department lethargic but awake and oriented $\mathrm{x} 3$ having received naloxone by EMS and was cooperative with the medical staff. His vitals on admission where remarkable for a heart rate of 110 , a blood pressure of $88 / 50 \mathrm{mmHg}$, and a temperature of $101 \mathrm{~F}$. He claimed that he took the entire weekend supply of methadone $(80 \mathrm{mg}$ methadone that was supposed to be divided to $40 \mathrm{mg}$ on Saturday and $40 \mathrm{mg}$ on Sunday) on the same day in an attempt to "feel high" and was not trying to "kill himself." His only complaint was acute bilateral hearing loss. Work up in the emergency department revealed severe respiratory acidosis $\left(\mathrm{pH}=7.2, \mathrm{CO}_{2}=57\right)$ with right side atelectasis on chest $\mathrm{X}$-ray, acute renal failure $(\mathrm{Cr}=3.1$ baseline 1.15$)$, possible
NSTEMI, and acute hearing loss. He was given ASA $325 \mathrm{mg}$ and was placed on IV fluids and bicarbonate, broad spectrum IV antibiotics, and heparin drip, given a dose of charcoal, placed on a 1:1 sitter, and admitted to the intensive care unit for further management and treatment.

On further questioning he stated that he had normal hearing up until the time that he had become stuporous. Immediately upon wakening and before receiving any medicines besides naloxone, he noticed that he had complete hearing loss bilaterally. He denied tinnitus or vertigo. Otoscopic exam was normal bilaterally.

The following day the patient was feeling better (mentally and physically), and his physical exam was unremarkable except for bilateral hearing loss which was still complete. Patient had leukocytosis of 14,000 and had a positive urine analysis, and he also spiked a temperature of $102 \mathrm{~F}$ that night while still on IV antibiotics. His d-dimer levels were elevated, and in the setting of hypoventilation, a lower extremity duplex was done and came back as negative. He was evaluated by critical care medicine, cardiology, toxicology, renal, and psychiatry. Patient was cleared by cardiology as his cardiac enzymes were trending down, and it was thought to be secondary to his acute kidney injury (to be sent home on ASA $81 \mathrm{mg}$ PO daily along with atorvastatin and metoprolol and was asked to follow up as an outpatient with a stress echo). His renal function continued to improve with IV fluids 


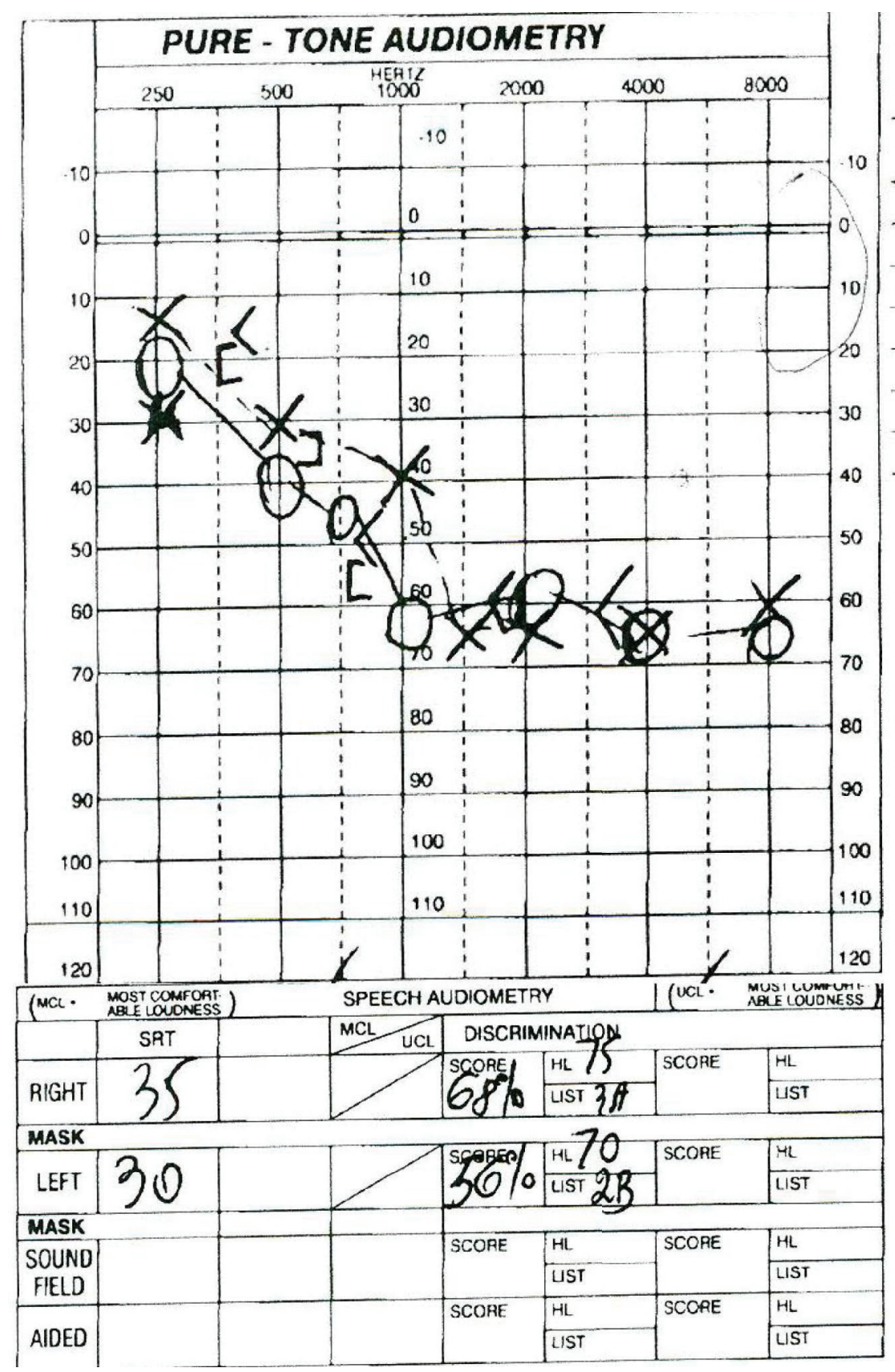

FIGURE 1: Audiometry graph one month after discharge.

(renal/bladder sonogram showed mild renal hydronephrosis. Urology was consulted and determined that there is no need for any intervention secondary to nonobstructing stone in patient with known history of nephrolithiasis versus methadone toxicity). Urine toxicology screen came back positive for methadone, benzodiazepines, and barbiturates, the latter two which he was supposed to have been detoxed off of recently. A CT scan of the chest was negative for pulmonary embolism. The decision by the critical care team was to continue the unit monitoring as he continued to spike fevers and have chills. Patient was restarted on methadone $40 \mathrm{mg}$ daily.
On the third day of admission he stated that, subjectively, his hearing had returned to thirty percent of normal and he was able to understand shouted words. Subsequently, the patient was sent to the medical floor with the active problems as follows: UTI, aspiration pneumonia, and IV site cellulitis. Meantime his hearing was improving slightly daily, although he remained far from baseline. Patient remained in the hospital for four days after that. On the medical floor his course was unremarkable, his vitals were stable, and patient was afebrile and more ambulatory. His subjective report of his hearing was improving day by day yet was still profoundly impaired, and he was given an appointment to see an ENT 


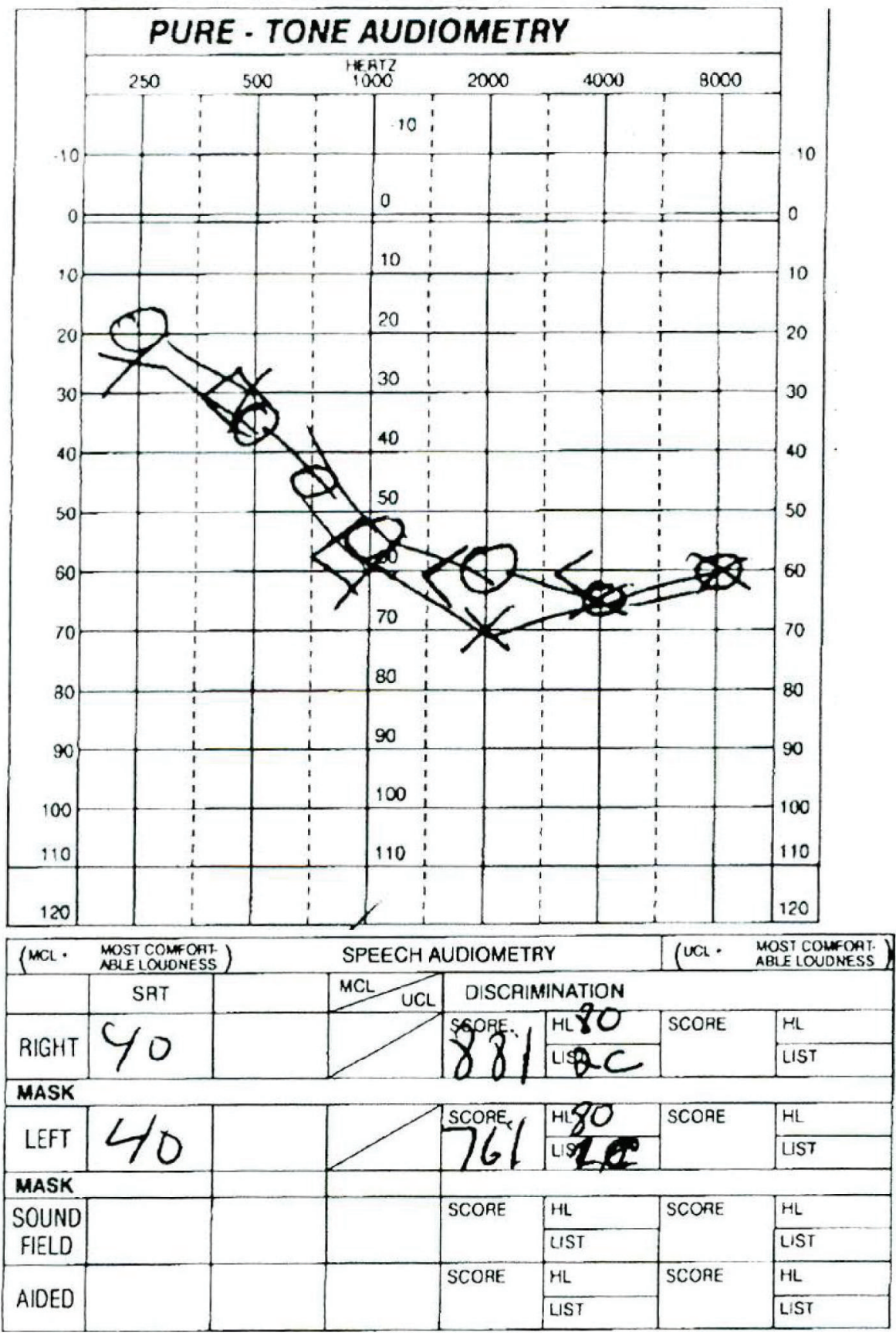

Figure 2: Audiometry graph two months after discharge.

as an outpatient. He was discharged after a full week of hospitalization on oral levaquin to follow up with cardiology and ENT and methadone clinic.

Three weeks after discharge, patient followed with ENT and reported that his hearing was slightly improved yet still profoundly impaired. He denied vertigo although complained of tinnitus which was new. He underwent an audiology evaluation one week later (Figure 1) which revealed normal hearing at $250 \mathrm{~Hz}$ sloping to a moderately severe sensorineural hearing loss bilaterally with poor speech discrimination. Tympanometry revealed normal middle ear function bilaterally, and acoustic reflexes were present bilaterally except for an absent reflex in the left ear at 2,000 Hz. The exam was repeated one month later (Figure 2) with similar results, and he was prescribed binaural hearing aids. After this time, he was lost to follow up.

\section{Discussion}

This case presents a 31-year-old man who chronically uses methadone who developed multisystem failure and sudden sensorineural hearing loss (SSHL) following an acute 
TABLE 1: Review of published cases of methadone induced hearing loss.

\begin{tabular}{|c|c|c|c|c|c|c|c|c|c|}
\hline Year & Authors & Age & Sex & Presentation & $\begin{array}{c}\text { Naloxone } \\
\text { given? }\end{array}$ & $\begin{array}{l}\text { Substances } \\
\text { Ingested }\end{array}$ & $\begin{array}{l}\text { Associated } \\
\text { conditions }\end{array}$ & $\begin{array}{l}\text { Methadone } \\
\text { withheld? }\end{array}$ & Followup \\
\hline 2009 & $\begin{array}{l}\text { Van Gaalen } \\
\text { et al. [1] }\end{array}$ & 37 & M & $\begin{array}{l}\text { Nausea, } \\
\text { confusion. } \\
\text { Deafness upon } \\
\text { awakening }\end{array}$ & Yes & Methadone & $\begin{array}{l}\text { Tinnitus, } \\
\text { bradypnea }\end{array}$ & Yes & $\begin{array}{l}\text { Complete } \\
\text { resolution by } \\
\text { day } 10\end{array}$ \\
\hline 2010 & $\begin{array}{l}\text { Christenson } \\
\text { et al. [2] }\end{array}$ & 30 & M & $\begin{array}{l}\text { Unresponsive and } \\
\text { apneic. Deafness } \\
\text { upon awakening } \\
\text { in ED following } \\
\text { naloxone }\end{array}$ & Yes & $\begin{array}{l}\text { Methadone (large } \\
\text { amount), cannabis, } \\
\text { alprazolam and } \\
\text { oxycodone (small } \\
\text { amount) }\end{array}$ & $\begin{array}{l}\text { Respiratory } \\
\text { failure, ARDS, } \\
\text { bradycardia, and } \\
\text { Hypotension }\end{array}$ & Unknown & $\begin{array}{l}\text { Resolution of } \\
\text { hearing loss } \\
\text { after } 24 \text { hours }\end{array}$ \\
\hline 2010 & $\begin{array}{l}\text { Christenson } \\
\text { et al. [2] }\end{array}$ & 25 & $\mathrm{~F}$ & $\begin{array}{l}\text { Unresponsive. } \\
\text { Deafness upon } \\
\text { awakening }\end{array}$ & Yes & $\begin{array}{l}\text { Methadone, } \\
\text { citalopram, cannabis } \\
\text { (all large amount), } \\
\text { and oxymorphone } \\
\text { (moderate amount) }\end{array}$ & $\begin{array}{l}\text { Tachycardia, } \\
\text { hypoxia }\end{array}$ & Yes & $\begin{array}{l}\text { Mild } \\
\text { improvement of } \\
\text { hearing by } 4 \\
\text { hours with } \\
\text { complete } \\
\text { resolution by } 24 \\
\text { hours }\end{array}$ \\
\hline 2011 & $\begin{array}{c}\text { Shaw et al. } \\
{[3]}\end{array}$ & 20 & M & $\begin{array}{l}\text { Stupor following } \\
\text { overdose. } \\
\text { Deafness upon } \\
\text { wakening }\end{array}$ & Yes & $\begin{array}{l}\text { Methadone, alcohol, } \\
\text { cannabis }\end{array}$ & $\begin{array}{l}\text { Respiratory } \\
\text { failure, } \\
\text { leukocytosis, } \\
\text { hypernatremia, } \\
\text { AKI, and } \\
\text { rhabdomyolysis }\end{array}$ & Yes & $\begin{array}{l}\text { Complete } \\
\text { resolution by } \\
\text { day } 4\end{array}$ \\
\hline 2012 & $\begin{array}{l}\text { Vorasubin } \\
\text { et al. [4] }\end{array}$ & 23 & M & $\begin{array}{l}\text { Respiratory } \\
\text { arrest. Deafness } \\
\text { upon awakening }\end{array}$ & Unknown & $\begin{array}{l}\text { Naltrexone, } \\
\text { methadone }\end{array}$ & $\begin{array}{l}\text { Respiratory } \\
\text { failure }\end{array}$ & Unknown & $\begin{array}{l}\text { Severe } \\
\text { sensorineural } \\
\text { hearing loss } \\
\text { above } 500 \mathrm{~Hz} \\
\text { persistent after } \\
\text { at least } 9 \text { months }\end{array}$ \\
\hline 2013 & $\begin{array}{l}\text { Saifan et al. } \\
\text { (this paper) }\end{array}$ & 31 & M & $\begin{array}{l}\text { Apnea. Deafness } \\
\text { upon awakening }\end{array}$ & Yes & $\begin{array}{l}\text { Methadone, } \\
\text { benzodiazepines, } \\
\text { and barbiturates }\end{array}$ & $\begin{array}{l}\text { Leukocytosis, } \\
\text { fever, AKI, UTI, } \\
\text { cellulitis, and } \\
\text { aspiration } \\
\text { pneumonia }\end{array}$ & No & $\begin{array}{l}\text { Severe } \\
\text { sensorineural } \\
\text { hearing loss } \\
\text { above } 250 \mathrm{~Hz} \\
\text { persistent after } \\
\text { at least } 2 \text { months }\end{array}$ \\
\hline
\end{tabular}

methadone overdose. SSHL has no single definition but is generally considered hearing loss occurring over less than 72 hours of at least 3 contiguous frequencies with many cases occurring over minutes. It is a rare condition affecting about two patients per 100,000 person-years [5]. Bilateral involvement as in our case is a rare phenomenon. Some patients also describe associated tinnitus, vertigo, or aural fullness [5]. SSHL can be caused by a number of etiologies such as infections agents, otologic disease, trauma, vascular insult, neoplastic disease, and miscellaneous causes but with the majority of cases-being idiopathic [5]. Many of these "idiopathic" causes are caused by autoimmune processes [6, 7] or rarely, drugs, including antibiotics-classically aminoglycosides, diuretics, chemotherapies, and anti-inflammatory agents [3].

Numerous case reports have described SSHL following opiate abuse or overuse. Most cases have involved either heroin [8-14] or hydrocodone/acetaminophen [15-18] with varying degrees of recovery. Recently, four case reports have described acute SSHL in five patients upon awaking from coma or stupor induced by acute methadone overdose [14] (Table 1). Although it is difficult to prove causality of methadone for the SSHL, the time course is a compelling indication that methadone may be the cause. At least five of the six reported patients (including our case) received naloxone which improved the patient's level of consciousness which lends support that the altered level of consciousness was due to an opiod medication in exclusion to other medications that the patient may have ingested. As none of the patients who received naloxone were cogent and able to report potential hearing loss until receiving therapy, we are unable to determine whether naloxone may have contributed to the deafness.

The etiology of SSHL caused by methadone remains unclear. The theory that unknown substances contaminated into the drug are what cause the SSHL, which had been proposed for heroin-induced SSHL, seems dubious for methadone produced by professional laboratories. One author has proposed that SSHL caused by opiates may be partially due to a genetic predisposition but offers no evidence 
or elucidation [16]. As opiate-induced SSHL is extremely rare, to our knowledge no study has systematically attempted to understand the mechanism.

Although most cases of opiate-induced SSHL are thought to involve a retrocochlear process, one reported case of chronic hydrocodone/acetaminophen abuses led to sensorineural hearing loss that only improved after the insertion of cochlear implants [16]. The improvement with cochlear implants seems to suggest that the chronic hearing loss associated with chronic opiate abuse must be a cochlear rather than retrocochlear process. However, it is not clear whether we can extrapolate such a case to our case in which an acute on chronic methadone overdose induced acute hearing loss.

This paper adds to the growing body of the literature describing cases of SSHL secondary to methadone overdose. Our patient is only the second in the literature to not make a full and speedy recovery following methadone-induced SSHL. Why two of the six reported patients failed to make a full recovery is unclear. However, it should be noted that in our case the patient continued to receive methadone at his usually prescribed dose. In the other reported cases of persistent hearing loss, it is not known whether the patient continued methadone or not. Methadone was withheld in all of the reported cases of improvement in which data is available.

In summary, methadone overdose may in rare cases cause SSHL.

\section{References}

[1] F. A. van Gaalen, E. A. Compier, and A. J. Fogteloo, "Sudden hearing loss after a methadone overdose," European Archives of Oto-Rhino-Laryngology, vol. 266, no. 5, pp. 773-774, 2009.

[2] B. J. Christenson, A. R. P. Marjala, and M. Foss, "Two cases of sudden sensorineural hearing loss after methadone overdose," Annals of Pharmacotherapy, vol. 44, no. 1, pp. 207-210, 2010.

[3] K. A. Shaw, K. M. Babu, and J. B. Hack, "Methadone, another cause of opioid-associated hearing loss: a case report," Journal of Emergency Medicine, vol. 41, no. 6, pp. 635-639, 2011.

[4] N. Vorasubin, A. Calzada, and A. Ishiyama, "Methadone induced irreversible bilateral severe sensorineural hearing loss," in Poster Presentation at the Triological Society's 115th Annual Meeting, San Diego, Calif, USA, April 2012.

[5] J. K. Chau, J. R. J. Lin, S. Atashband, R. A. Irvine, and B. D. Westerberg, "Systematic review of the evidence for the etiology of adult sudden sensorineural hearing loss," Laryngoscope, vol. 120, no. 5, pp. 1011-1021, 2010.

[6] E. Toubi, K. Halas, J. Ben-David, E. Sabo, A. Kessel, and M. Luntz, "Immune-mediated disorders associated with idiopathic sudden sensorineural hearing loss," Annals of Otology, Rhinology and Laryngology, vol. 113, no. 6, pp. 445-449, 2004.

[7] M.-J. Baek, H.-M. Park, J. M. Johnson et al., "Increased frequencies of cochin-specific T cells in patients with autoimmune sensorineural hearing loss," Journal of Immunology, vol. 177, no. 6, pp. 4203-4210, 2006.

[8] G. Mulch and M. Handrock, "Sudden binaural deafness after acute heroin intoxication," Laryngologie Rhinologie Otologie, vol. 58 , no. 5, pp. 435-437, 1979.
[9] S. Polpathapee, P. Tuchinda, and S. Chiwapong, "Sensorineural hearing loss in a heroin addict," Journal of the Medical Association of Thailand, vol. 67, no. 1, pp. 57-60, 1984.

[10] S. Kortequee, F. O. Agada, and A. P. Coatesworth, "Sudden sensorineural hearing loss following intracarotid injection of heroin," International Journal of Clinical Practice, vol. 59, no. 147, pp. 128-129, 2005.

[11] A. Schrock, M. Jakob, S. Wirz, and F. Bootz, "Sudden sensorineural hearing loss after heroin injection," European Archives of Oto-Rhino-Laryngology, vol. 265, no. 5, pp. 603-606, 2008.

[12] C. G. Fowler and J. L. King, "Sudden bilateral sensorineural hearing loss following speedballing," Journal of the American Academy of Audiology, vol. 19, no. 6, pp. 461-464, 2008.

[13] E. L. Nair, K. M. Cienkowski, and E. Michaelides, "The impact of sudden hearing loss secondary to heroin overdose on fitting outcomes," American Journal of Audiology, vol. 19, no. 2, pp. 8690, 2010.

[14] S. Antonopoulos, D. G. Balatsouras, S. Kanakaki, A. Dona, C. Spiliopoulou, and G. Giannoulis, "Bilateral sudden sensorineural hearing loss caused by alcohol abuse and heroin sniffing," Auris Nasus Larynx, vol. 39, no. 3, pp. 305-309, 2012.

[15] R. A. Friedman, J. W. House, W. M. Luxford, S. Gherini, and D. Mills, "Profound hearing loss associated with hydrocodone/acetaminophen abuse," American Journal of Otology, vol. 21, no. 2, pp. 188-191, 2000.

[16] A. K. Oh, A. Ishiyama, and R. W. Baloh, "Deafness associated with abuse of hydrocodone/acetaminophen," Neurology, vol. 54, no. 12, p. 2345, 2000.

[17] T. Ho, J. T. Vrabec, and A. W. Burton, "Hydrocodone use and sensorineural hearing loss," Pain Physician, vol. 10, no. 3, pp. 467-472, 2007.

[18] B. W. Blakley and H. Schilling, "Deafness associated with acetaminophen and codeine abuse," Journal of Otolaryngology, vol. 37, no. 4, pp. 507-509, 2008. 


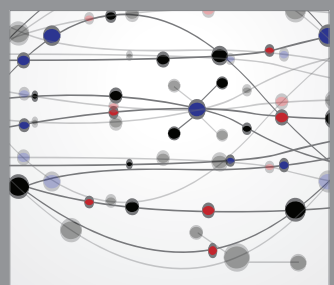

The Scientific World Journal
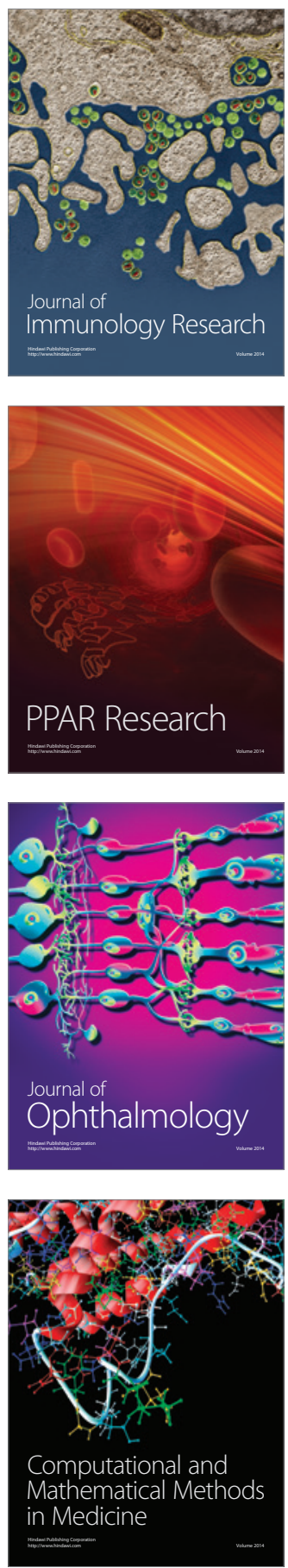

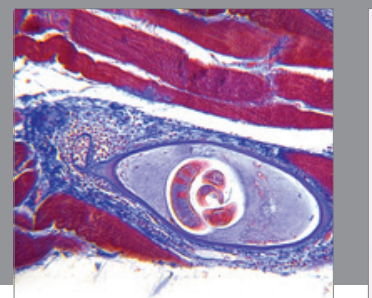

Gastroenterology

Research and Practice
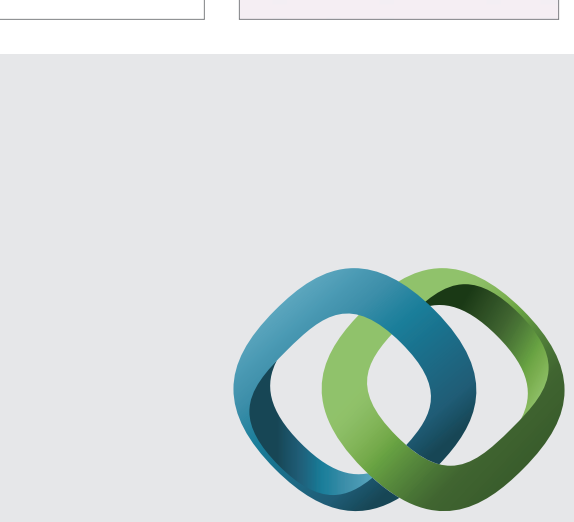

\section{Hindawi}

Submit your manuscripts at

http://www.hindawi.com
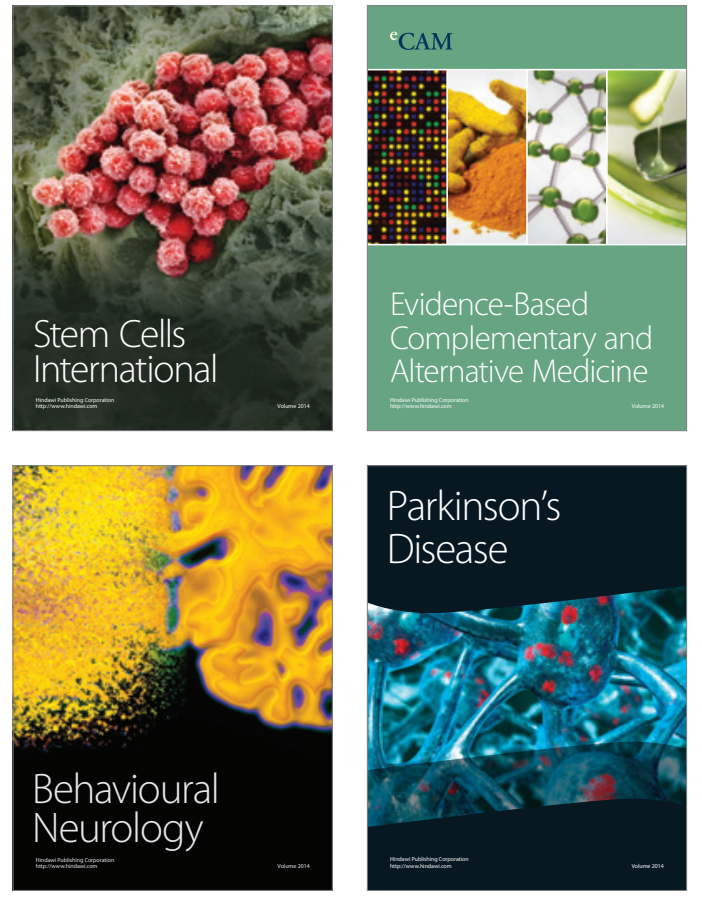
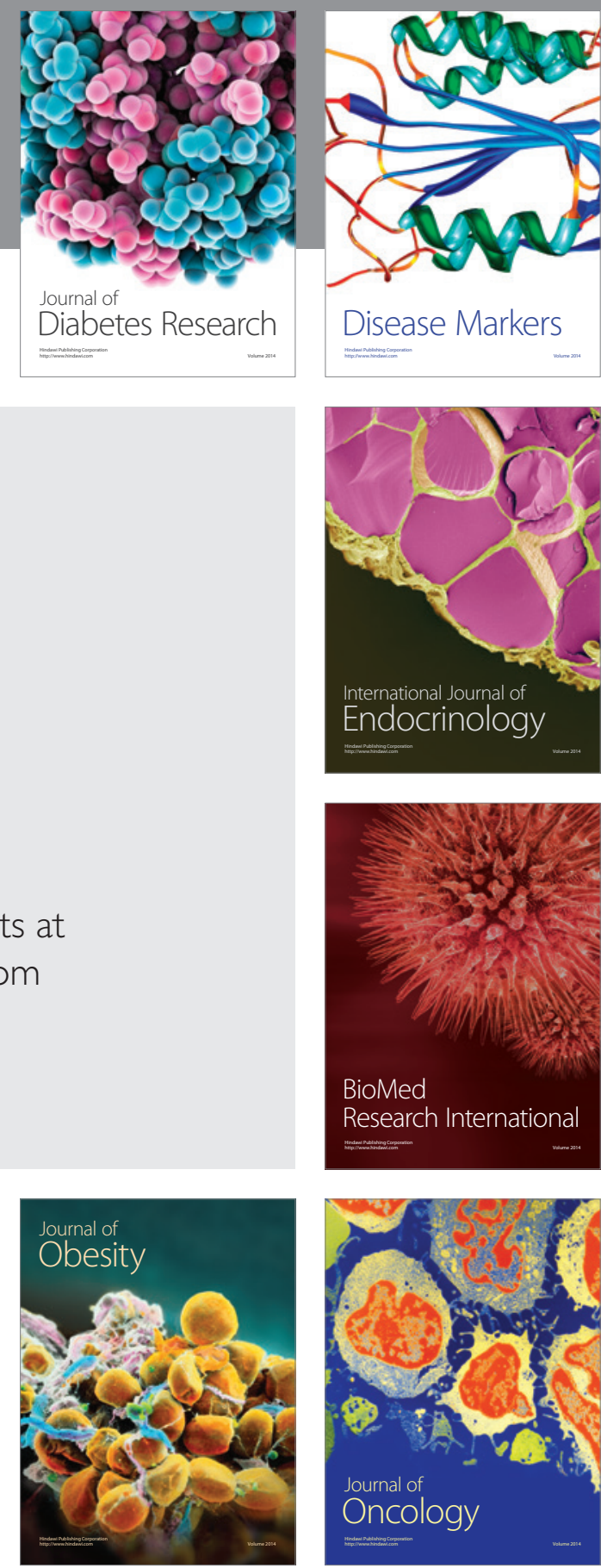

Disease Markers
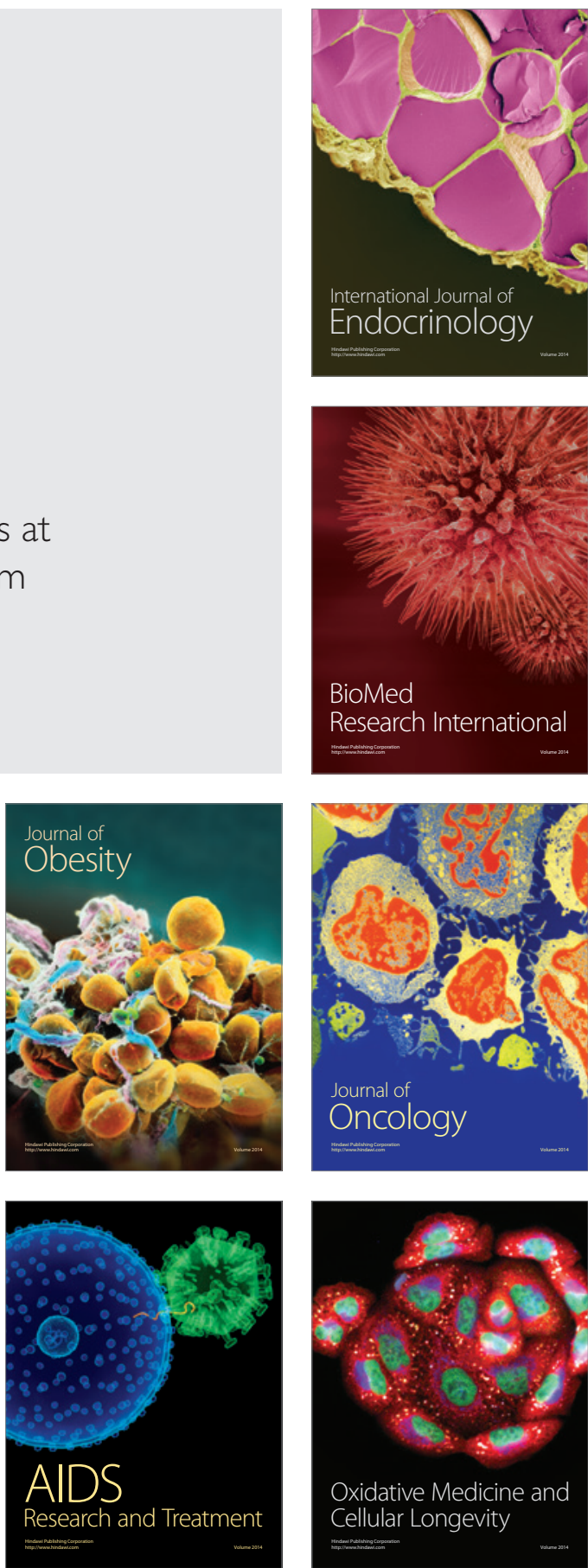